\title{
Regional variation in the life cycle of Rhincalanus gigas (Copepoda: Calanoida) in the Atlantic Sector of the Southern Ocean-re-examination of existing data (1928 to 1993)
}

\author{
P. Ward ${ }^{1, *}$, A. Atkinson ${ }^{1}$, S. B. Schnack-Schiel ${ }^{2}$, A. W. A. Murray ${ }^{1}$ \\ 'British Antarctic Survey, Natural Environment Research Council, High Cross, Madingley Road, Cambridge CB3 0ET, \\ United Kingdom \\ ${ }^{2}$ Alfred-Wegener-Institut für Polar- und Meeresforschung, Columbusstraße, D-27568 Bremerhaven, Germany
}

\begin{abstract}
A regional comparison of the life cycle of Rhincalanus gigas was undertaken on the basis of selected net haul data collected in the Atlantic sector of the Southern Ocean between the years 1928 and 1993. Data were pooled into 3 regions, a northern region (NR) extending from the Scotia Sea to the sub-Antarctic Front and incorporating the Polar Front and Polar Frontal Zone, the Weddell-Scotia Confluence (WSC) and the Eastern Weddell Sea (EWS). There are distinct regional contrasts in the physical environment, the NR being largely ice-free throughout the year compared to the 9 mo ice cover found in the EWS. R. gigas was more abundant in the NR, particularly at the Polar Front, than in either the WSC or EWS and seasonal fluctuations in abundance in all regions were low. A clear seasonal vertical migration pattern was found in the NR and EWS, with the population commencing its descent in February in both; however, arrival back in the surface waters was up to 2-3 mo earlier in the NR and recruitment commenced correspondingly sooner. In the WSC no clear seasonal pattern could be resolved, which probably reflects this region's dynamic nature. Clear differences in overwintering stage structure were also seen between the NR and EWS. In the former, the new generation overwinters mainly as CIII, compared to CII in the EWS. A winter decline in the abundance of CIV to CVI in the NR and their clear recruitment from October onwards suggests that a proportion of the population has a 1 yr life cycle. In contrast in the EWS a strong overwintering presence of CIV to CVI suggests that 2 y is more likely. In both regions females were present throughout the year indicating their ability to overwinter and possibly spawn again. Low mortality rates $\left(<0.004 \mathrm{~d}^{-1}\right)$ in both regions during the autumn and winter offer further support for a 2 yr life cycle.
\end{abstract}

KEY WORDS: Rhincalanus gigas - Life cycle Southern Ocean - Regional variation Development rates - Mortality

\section{INTRODUCTION}

Primary production in the Antarctic pelagial is markedly seasonal and this has major effects on the life cycles of many of its inhabitants. Regional variations in the nature, extent and timing of primary production are pronounced (Tréguer \& Jacques 1992, Laubscher

•E-mail: pwar@pcmail.nerc-bas.ac.uk et al. 1993) and are reflected in species ecology. Whilst the response of the dominant copepod species to this seasonality has in the past appeared superficially similar, recent research has demonstrated distinct differences in certain aspects of their biology. Thus lipid storage patterns (Hagen et al. 1993, Kattner \& Hagen 1995, Ward et al. 1996b), diet (Hopkins \& Torres 1989, Hopkins et al. 1993, Atkinson 1994, 1995), patterns of seasonal migration (Marin 1988a, Atkinson 1991) and the timing of reproduction (Marin 1988a, Atkinson 1991, Ward et al. 1996b) have all been shown to differ. 
Of the biomass-dominant copepods in the Southern Ocean the life-history and ecology of Rhincalanus gigas is arguably the least well understood. This large eucalaniid has a widespread distribution, occurring in the sub-Antarctic to the north and as far south as the Antarctic Coastal Current although it is essentially an inhabitant of the Polar Frontal Zone (Ommanney 1936).

Estimation of rates of growth and development and life-cycle duration of Rhincalanus gigas has remained problematic largely because of logistic difficulties in adequately sampling the wide area over which this species occurs. Interpretations are made more difficult by the fact that much of the sampling has been carried out in the short austral summer and out of necessity data have to be spatially and temporally averaged. Stage frequency distributions of $R$. gigas thus often fail to clearly show cohorts and their progression. Estimates of generation time accordingly vary from 1 to
2 yr and a 'flexibility' has been attributed to its life cycle (Marin 1988a, b) which may mask real spatial and temporal differences.

In an attempt to understand more of the ecology of Rhincalanus gigas we have re-examined available data on its abundance, stage composition and vertical distribution on a regional basis. Most data are available from the South Atlantic sector between $0^{\circ}$ and $80^{\circ} \mathrm{W}$ and so we have compiled existing data sets and grouped them into 3 main areas (Fig. 1). First, a northern region (NR) including stations worked in the subAntarctic and Polar Frontal Zones and the Scotia Sea, second, from samples taken within the Weddell-Scotia Confluence (WSC) and third, in the Eastern Weddell Sea (EWS). We have focused on determining the extent to which life-cycle characteristics vary in these regions and assessing the concept of a flexible life cycle.

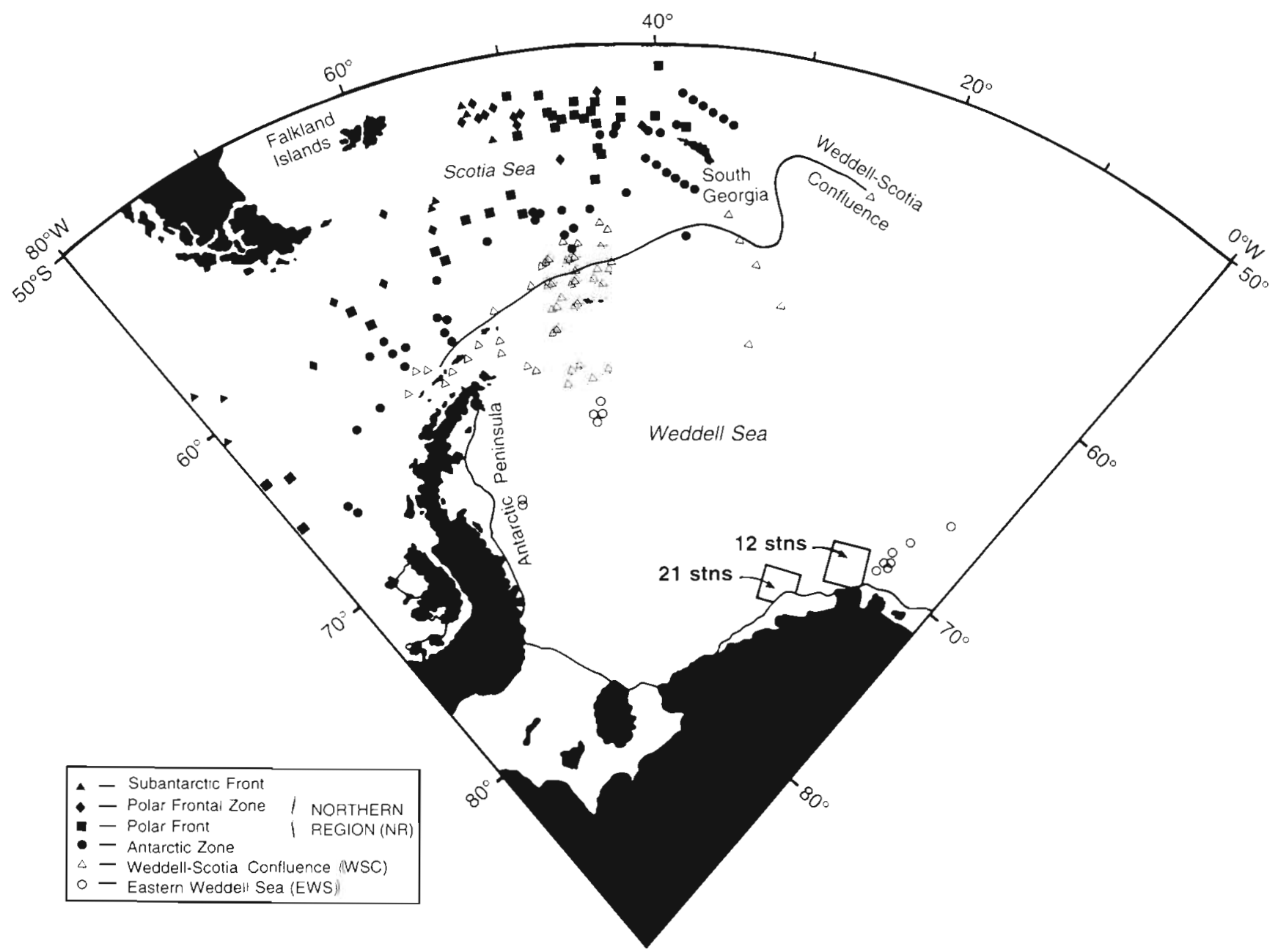

Fig. 1. Position of sampling stations classified by temperature according to Atkinson et al. (1997). NB: stations classified as EWS include 6 from the Western Weddell Sea (see Table 3) 


\section{METHODS}

Criteria for the discrimination of water masses and for the acceptance of data are as detailed in Atkinson. et al. (1997). Briefly, published and unpublished data sets on abundance and developmental stage structure of Rhincalanus gigas in the $0^{\circ}$ to $80^{\circ} \mathrm{W}$ sector were evaluated and those that met the following criteria were included: (1) all hauls should have been carried out in water exceeding $1000 \mathrm{~m}$ depth; (2) nets should where possible have fished to $1000 \mathrm{~m}$ so as to adequately sample the majority of the population at all times of year; and (3) in order to adequately sample juvenile stages, net mesh should not exceed $200 \mu \mathrm{m}$. Exceptions to these criteria were made in the case of a series of summer SIBEX (Second International Biological Experiment) stations located principally in the WSC, where nets were fished to $500 \mathrm{~m}$ and for winter and summer sample sets from South Georgia where a $330 \mu \mathrm{m}$ net was used. Given the time of year and the anticipated depth distribution and stage structure of the population we judged that the species was quantitatively sampled on all occasions.
Data used in this analysis are summarized in Tables $1-3$ and station positions are given in Fig. 1 .

For an organism such as Rhincalanus gigas whose life span appears to be measurable in months to years the 3 regions selected represent the appropriate spatial scale of investigation. Although the $N R$ is broad in extent, and includes the Polar and sub-Antarctic fronts, further sub-division into regional sub-areas would have meant a reduction in their seasonal coverage, rendering comparisons at this scale difficult. However, $R$. gigas is widespread throughout this zone, particularly in comparison to the Weddell Sea, and a preliminary examination showed that there was no significant restriction in the spread of samples with respect to time of year, although the number available for each subarea varied. We therefore concluded that it was appropriate to include all samples that met the previously defined criteria without introducing sub-regional bias. Regional boundaries are not geographically fixed and movement of water masses, particularly in frontal regions, can be significant. Grouping of stations into regions was therefore accomplished according to temperature at depth (see Atkinson 1991, Atkinson et al.

Table 1. Northern Region (NR) stations selected for analysis. Falks: Falkland Islands; AKN: Akademik Knipovich; JB: John Biscoe; WS: William Scoresby; E: Eltanin; D: Discovery Il; P: Polarstern; AKU: Akademik Kurchatov

\begin{tabular}{|c|c|c|c|c|c|c|}
\hline Date & Position of stations & Ship & Stations & $\begin{array}{l}\text { Net depth }(\mathrm{m}) \\
\text { (no. of strata) }\end{array}$ & Source & Notes \\
\hline 5-7 Aug 1971 & Falks-S Georgia & $A K N$ & 343536373839 & $1000(5)$ & Voronina et al. (1978) & Percentages only \\
\hline 27 Jul-20 Aug 1983 & Near S Georgia & $\mathrm{JB}$ & 12 unnamed stns & $1000(3)$ & Atkinson (1989) & RMT 1 (330 m) \\
\hline 20-24 Aug 1928 & Falks-S Georgia & WS & 252253254255256 & $1000(6)$ & Atkinson (1991) & \\
\hline 1 Sep 1963 & South of S Georgia & $E$ & 180 & $1000(3)$ & Marin $(1986)$ & \\
\hline Sep 1971 & S Scotia Sea & $\mathrm{AKN}$ & 114 & $1000(6)$ & Vladimirskaya (1978) & \\
\hline 26 Sep 1971 & E Scotıa Sea & AKN & 111 & $1000(5)$ & Voronına et al. (1978) & Percentages only \\
\hline $26-28$ Oct 1932 & Along $80^{\circ} \mathrm{W}$ & $\mathrm{D}$ & 987989991993 & $1000(6)$ & Atkinson (1991) & \\
\hline 9-13 Nov 1929 & Across Scotla Sea & WS & 468469470471.473 & $1000(6)$ & Atkinson (1991) & \\
\hline 26 Nov 1988 & S Scotia Sea & $\mathrm{P}$ & 143 & $1000(5)$ & Schnack-Schiel (unpubl. data) & \\
\hline 18-20 Nov 1932 & E Scotıa Sea & $\mathrm{D}$ & 10281030 & $1000(6)$ & Atkınson (1991) & \\
\hline 24 Nov-19 Dec 1981 & Around S Georgua & $J B$ & Average of 9 oceanic stns & $1000(3)$ & Atkinson (1989) & \\
\hline 2-5 Dec 1928 & S Georgia-Falks & WS & 315316317318 & $1000(6)$ & Atkinson (1991) & \\
\hline 11-13 Dec 1988 & S Scotıa Sea & $\mathrm{P}$ & $159 b 160162$ & $1000(5)$ & Schnack-Schiel (unpubl. data) & \\
\hline 13-14 Dec 1971 & Central Scotia Sea & AKU & 912915 & $1000(5)$ & Voronina et al. (1978) & Percentages only \\
\hline 28 Dec-1 Jan 1934 & Drake Passage & $\mathrm{D}$ & 12331234123512361237 & $1000(5-6)$ & Atkinson (1991) & \\
\hline $17 \operatorname{Jan} 1989$ & S Scotia Sea & $\mathrm{P}$ & 213 & $1000(5)$ & Schnack-Schiel (unpubl. data) & \\
\hline $18-21 \operatorname{Jan} 1990$ & Near S Georgia & $\mathrm{JB}$ & Oceanic stn & $800(21)$ & Ward et al. (1995) & LHPR data \\
\hline 24-25 Jan 1935 & Central Scotia Sea & $\mathrm{D}$ & 149314941495 & $1000(6)$ & Atkinson (1991) & \\
\hline Jan/Feb 1966 & Central N Scotia Sea & $E$ & 515521 & $1000(5)$ & Marin (1986) & \\
\hline 27 Jan-5 Feb 1985 & S Shetlands & $\mathrm{JB}$ & 34354244495051 & $500(2)$ & SIBEX stns (unpubl. data) & $\operatorname{RMT} 1(330 \mathrm{~m})$ \\
\hline $9-15$ Feb 1928 & Falks-S Georgia & WS & 138139140141143 & $1000(5-6)$ & Atkinson (1991) & \\
\hline 22-24 Feb 1929 & Drake Passage & WS & 402403404405 & $1000(6)$ & Atkinson (1991) & \\
\hline 27 Feb-3 Mar 1930 & Falks-S Georgla & WS & 520521522523524526 & $1000(6)$ & Atkinson (1991) & \\
\hline 4-7 Apr 1930 & Central Scotia Sea & $\mathrm{D}$ & 13351337 & $1000(6)$ & Atkinson (1991) & \\
\hline 22-26 Apr 1929 & Central Scotia Sea & WS & 203204205 & $1000(6)$ & Atkinson (1991) & \\
\hline 29 Apr-1 May 1929 & S Georgia-Falks & WS & 428429430431 & $1000(6)$ & Atkinson (1991) & \\
\hline 28-29 May 1936 & Along $0^{\circ}$ meridian & $\mathrm{D}$ & 17761777 & $1500(7)$ & Atkinson (1991) & \\
\hline 21-25 Jun 1951 & W of Drake Passage & $\mathrm{D}$ & 284128422844 & $1500(7)$ & Atkinson (1991) & \\
\hline $6-8$ Jul 1951 & Central/Eastem Scotia Sea & $D$ & 284928502851 & $1500(7)$ & Atkinson (1991) & \\
\hline
\end{tabular}


Table 2. Weddell-Scotia Confluence (WSC) stations selected for analysis. See Table 1 for abbreviations

\begin{tabular}{|c|c|c|c|c|c|c|}
\hline Date & Position of stns & Ship & Stations & $\begin{array}{l}\text { Jet depth (m } \\
\text { no. of strata. }\end{array}$ & Source & Notes \\
\hline Aug-Sep 1963 & SOrkneys area & $E$ & 178179181183184185 & $1000(?)$ & Marin (1986) & Percentages only \\
\hline Mid Sep 1971 & S Orkneys area & $A K N$ & 122123125 & $1000(6)$ & Vladimirskaya (1978) & \\
\hline 12 Nov 1988 & S Orkneys area & $P$ & 134136137 & $1000(5)$ & Schnack-Schiel (unpubl.) & \\
\hline 21 Nov 1932 & S Orkneys area & $\mathrm{D}$ & 1032 & $2000(6)$ & Atkinson (1991) & \\
\hline 27 Nov-5 Dec 1988 & S Orkneys area & $\mathrm{P}$ & 145147149151153157 & $1000(5)$ & Schnack-Schiel (unpubl.) & \\
\hline 11-16 Dec 1988 & S Orkneys area & $P$ & 164166168 & $1000(5)$ & Schnack-Schiel (unpubl.) & \\
\hline 26-31 Dec 1988 & S Orkneys area & $\mathrm{P}$ & 182186188190192194 & $1000(5)$ & Schnack-Schiel (unpubl.) & \\
\hline $17-19 \operatorname{Jan} 1989$ & S Orkneys area & $\mathrm{P}$ & 214215216218219 & $1000(5)$ & Schnack-Schiel (unpubl.) & \\
\hline $23 \operatorname{Jan} 1935$ & S Orkneys area & $\mathrm{D}$ & 14911492 & $1000(6)$ & Atkinson (1991) & \\
\hline $16 \mathrm{Jan}-3$ Feb 1985 & S Shetlands area & $\mathrm{JB}$ & 9 stns & $500(2)$ & Ward (unpubl.) & SIBEX stns \\
\hline 21 Feb 1929 & S Shetlands areà & WS & 400 & $1000(6)$ & Atkinson (1991) & \\
\hline Mar-Apr (1964) & $\begin{array}{l}\text { S Shetlands-S } \\
\text { Sandwich Islands }\end{array}$ & E & 262264274275278287 & $1000(5)$ & Marin (1986) & \\
\hline 4-5 Apr 1934 & North of SOrkneys & 5 & 13311333 & $1000(6)$ & Atkinson (1991) & \\
\hline 22 Apr 1934 & S Orkneys area & WS & 201 & $1000(6)$ & Atkinson (1991) & \\
\hline 1-2 Jun 1936 & Along $0^{\circ}$ meridian & $\mathrm{D}$ & 17791781 & $1000(6)$ & Atkinson (1991) & \\
\hline 9-19 Jul 1951 & South of S Georgia & $\mathrm{D}$ & 2852 & 2853 & Atkinson (1991) & \\
\hline
\end{tabular}

Table 3. Eastern Weddell Sea (EWS) stations selected for analysis. All stations worked by 'Polarstern'

\begin{tabular}{|c|c|c|c|c|}
\hline Date & Stations & $\begin{array}{l}\text { Net depth }(\mathrm{m}) \\
\text { (no. of strata) }\end{array}$ & Source & Notes \\
\hline $5-16$ Oct 1988 & 181183187193199203 & $2000(5)$ & Bathmann et al. (1993) & Net only to $1000 \mathrm{~m}$ at Stn 187 \\
\hline $17-22$ Oct 1986 & 512513514516526 & $1000(5)$ & Schnack-Schiel \& Hagen (1994) & \\
\hline 3-5 Nov 1986 & 562565570 & $1000(5)$ & Schnack-Schiel \& Hagen (1994) & \\
\hline $17-24$ Nov 1986 & 604607611614618623 & $1000(5)$ & Schnack-Schiel \& Hagen (1994) & \\
\hline 25 Nov 1990 & 48 & $1000(5)$ & Schnack-Schiel (unpubl.) & Western Weddell Sea \\
\hline 14-22 Dec 1992 & 15192131 & $1000(5)$ & Schnack-Schiel (unpubl.) & \\
\hline 8-16 Jan 1993 & 5962688084 & $1000(5)$ & Schnack-Schiel (unpubl.) & Western Weddell Sea \\
\hline 29 Jan 1985 & 278279 & $1000(5)$ & Schnack-Schiel \& Hagen (1994) & \\
\hline 15 Feb 1985 & 331332333334 & $1000(5)$ & Schnack-Schiel \& Hagen (1994) & Haul 331 to $900 \mathrm{~m}$ \\
\hline 12-13 Apr 1992 & 359367369373 & $1000(5)$ & Schnack-Schiel \& Hagen (1994) & \\
\hline 26 Apr-2 May 1992 & 452455461467472474 & $1000(5)$ & Schnack-Schiel \& Hagen (1994) & Haul 474 to $850 \mathrm{~m}$ \\
\hline
\end{tabular}

1997), which also obviated the need to interpret the variable effects of seasonal warming on the mixed layer.

\section{RESULTS}

\section{Environment}

Despite the fact that the areas contrasted in the following analysis form a geographical continuum there are distinct physical differences which justify their separation. The NR is largely free of seasonal ice cover and is dominated by the northeastwards flowing Antarctic Circumpolar Current (ACC). Within this area the Scotia Sea is bounded to the south and east by the WSC and to the north and west by the Antarctic Polar Front (APF) beyond which lies the Polar Frontal Zone
(PFZ) and in turn the sub-Antarctic Front (SAF). Although the temperature range in the surface layers across this region may be as much as $9^{\circ} \mathrm{C}$, for up to $75 \%$ of the year the population resides in deeper water where temperature differences are less marked. During an individual's lifetime in the region it is likely to be transported considerable distances, broadly speaking north and eastwards in summer and southwards during winter, following its seasonal descent (Mackintosh 1937). The NR as a whole largely corresponds to the Polar Open Ocean Zone (POOZ) (Tréguer \& Jacques 1992) where primary production is variable but generally low (Savidge et al. 1996) and the area is considered to be oligotrophic. However, the PFZ is thought to be considerably more productive with an estimated annual primary production of $80 \mathrm{~g} \mathrm{C} \mathrm{m}^{-2} \mathrm{yr}^{-1}$ compared with $<40 \mathrm{~g} \mathrm{C} \mathrm{m}^{-2} \mathrm{yr}^{-1}$ elsewhere in the Southern Ocean (Wefer \& Fischer 1991). 


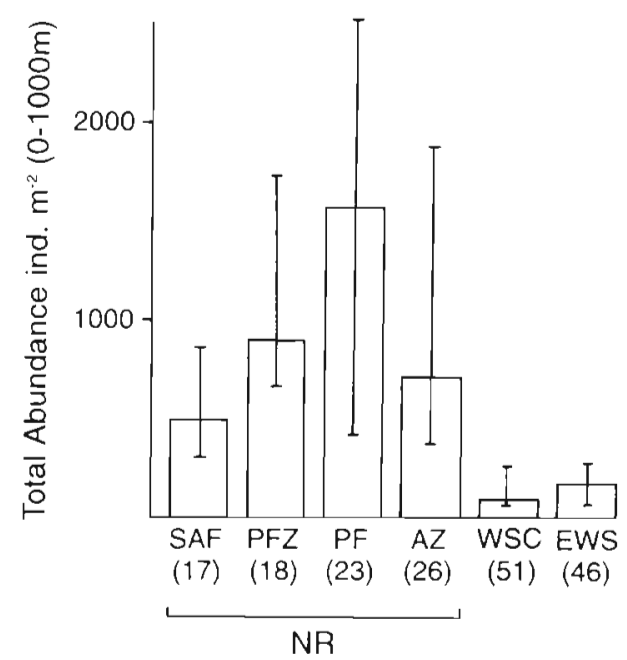

Fig. 2. Rhincalanus gigas. Median total copepodite abundance (0 to $1000 \mathrm{~m}$ ) averaged over the year with respect to the regions and sub-regions referred to in the text. Bars represent inter-

quartile ranges. Number of hauls given in parentheses

As a region the WSC is the smallest, being bordered to the north by the ACC and to the south by the Weddell Sea. It is a transition zone between these 2 water masses and is characterized by approximately 5 mo of seasonal ice cover (Gloersen et al. 1992), weak stratification and the presence of Weddell shelf water (Whitworth et al. 1994). Its influence can be traced eastwards beyond the $0^{\circ}$ meridian (Orsi et al. 1993). Stations in this region include some that although geographically situated in the NW Weddell Sea had temperature profiles that corresponded to WSC water. At the most southerly extent the EWS forms part of the Weddell Gyre, a region of both permanent and seasonal ice cover fed by the Antarctic Coastal Current, within which the annual temperature range in the surface waters is $<3^{\circ} \mathrm{C}$. Open water is present at most for about $3 \mathrm{mo} \mathrm{yr}^{-1}$. Primary production in this region proceeds in a widely differing number of environments, notably the marginal ice zone, the closed pack ice (also within the ice itself) and in the coastal and continental zones where in certain areas katabatic winds lead to the formation of coastal polynyas. Dense blooms have also been recorded during periods of ice formation during summer (Sakshaug 1989) and fringing the ice shelf in late winter/early spring (Smetacek et al. 1992). The amount and availability of food are thus variable and the ability of the individual to exploit it will depend on where in the system the individual is located.

\section{Total abundance}

Median abundance values (Fig. 2) demonstrate regional differences and show that within the NR

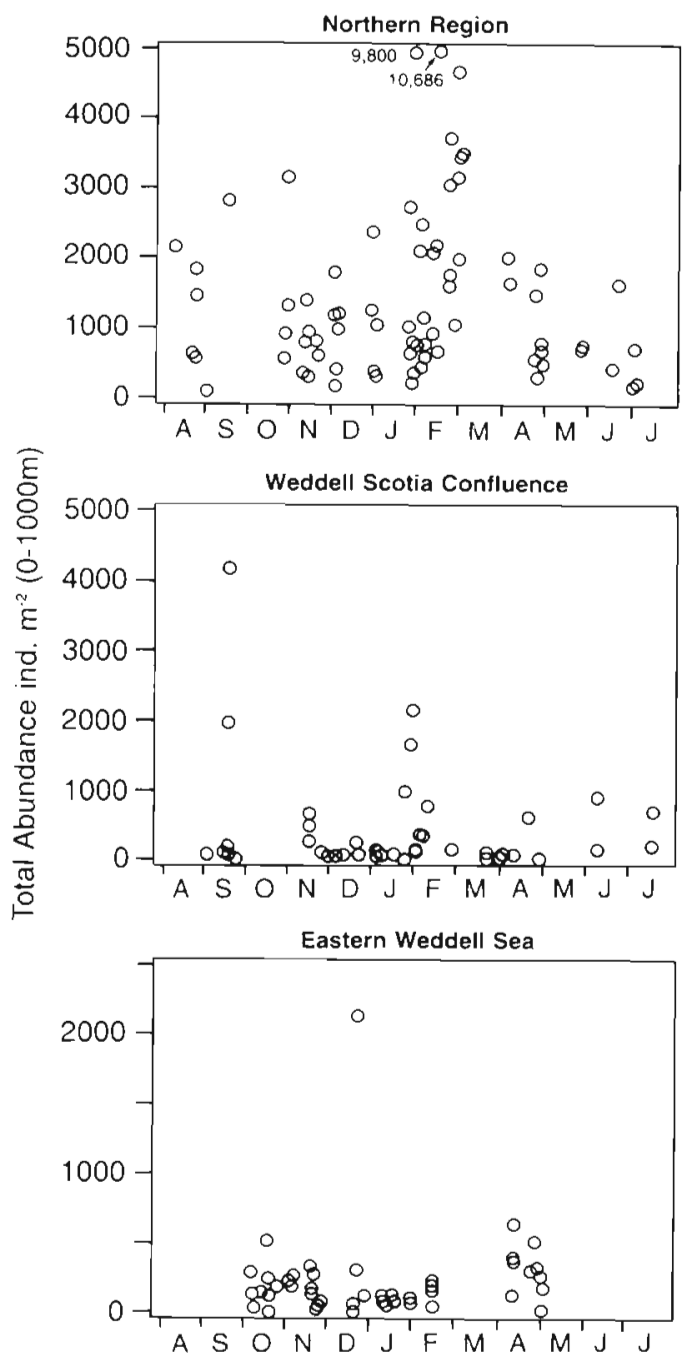

Fig. 3. Rhincalanus gigas. Total population abundance (all stages) $(0$ to $1000 \mathrm{~m})$ in the 3 regions with respect to time of year

abundance is highest in the region of the PF and lowest in the SAF. The possibility of seasonal bias across regions was investigated by plotting data within concurrent $90 \mathrm{~d}$ periods running from August 1. Results confirmed the clear differences among the 3 major regions and showed minor seasonal differences within the sub-regions to the north, although maximum abundance was found in all in the February-March period. Abundances in the EWS and the WSC are considerably lower than in the NR.

Total abundance data (excluding nauplii) for all 3 regions are presented in Fig. 3. In all 3 regions seasonal fluctuations are low, a clear increase only being seen in the NR coincident with the main period of recruitment. The absence of such an increase in the EWS is probably attributable to the fact that the more restricted sampling regime was not coincident with periods of maximal recruitment. The 2 outlying abun- 
dance values in the NR that approach 10000 ind. $\mathrm{m}^{-2}$ (Fig. 3) were both dominated by younger stages and were broadly coincident in time ( $20 \mathrm{~d}$ difference) but were from different years and different sub-areas within the region, offering some independent confirmation of homogeneity throughout the region. In the WSC total abundance was extremely variable with increased totals due to recruitment occurring around January, being exceeded by several values in September when the population was dominated by older stages.

\section{Vertical distribution}

The regional vertical distribution of Rhincalanus gigas has been well described and calculated on a seasonal basis by a number of authors (Voronina 1970, Marin 1988a, b. Atkinson 1991, Schnack-Schiel \& Hagen 1994). It is not our intention to reiterate their data in that form, rather to compare the depth distribution of the regional populations using the median population depth. In the NR and EWS a clear seasonality was evident, with an increase in population median depth during winter (Fig. 4). Despite differences in sample coverage between these 2 regions it is clear that the timing of the seasonal ascent differs such that the northern population arrives in the surface waters around the beginning of November, some 2 to 3 mo earlier than the EWS population. The winter descent commences from February in both regions, the net effect being that animals in the EWS appear to spend less time in the surface waters. However, this was not the case for the WSC where there was no clear seasonal pattern and population median depth was extremely variable. In all regions the population median depth changes throughout the year and is not static for any appreciable period of time. Eight hauls taken to $1500 \mathrm{~m}$ in the Scotia Sea mainly during June and early July and to $2000 \mathrm{~m}$ in the Weddell Sea (mid September to mid October; Bathmann et al. 1993) indicated that the proportion of the population residing deeper than $1000 \mathrm{~m}$ averaged 5 to $11 \%$.

\section{Developmental stage structure}

It is necessary to summarize both percentage composition and stage abundance (Fig. $5 a \&$ b respectively) as these represent temporally and spatially averaged data and either on its own may be misleading. For instance whilst recruitment clearly increases the proportion of younger stages in the population, the corresponding percentage decline in the older stages does not necessarily imply an absolute decrease in num-
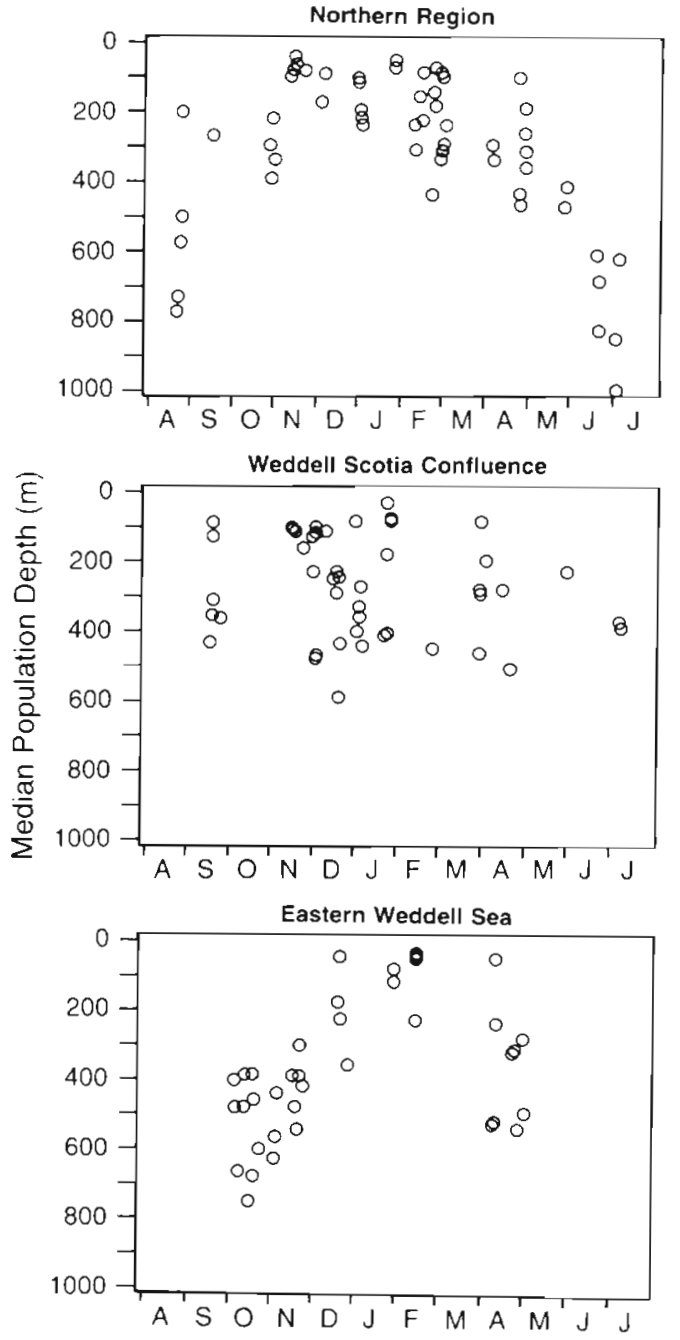

Fig. 4. Rhincalanus gigas. Median population depth with respect to time of year for the 3 regions. Interpolated from the standardised catch data (ind. $\mathrm{m}^{-2}, 0$ to $1000 \mathrm{~m}$ ) as the depth at which $50 \%$ of the population lies above and $50 \%$ below

bers. The appearance of males in the population appeared to follow a similar pattern in all 3 regions. Following the autumn and early winter period when they formed a negligible proportion of the total population, increases occurred from August-September onwards with a peak of $-10 \%$ being reached at about the time the population reached the surface waters, i.e. early November in the NR, December in the WSC and February in the EWS. A similar trend was seen for females which achieved maxima (up to $50 \%$ of the population, and somewhat more in the WSC) at the same time. Although females subsequently declined a proportion appeared to overwinter in all regions. Recruitment of Cls commenced shortly after the arrival of the population in surface waters. Because of the relatively poor temporal coverage in the EWS at this time 
CIs were not observed until April although the nearest previous sampling date in February failed to disclose any. Very few CIs overwintered in any region. From this point onwards the simple correspondence in stage distribution observed between regions, albeit offset by 2 to 3 mo, disappeared. In the NR CIIs and CIIIs appeared shortly after CIs and the proportion of both stages passing through into autumn and early winter was highly variable. Data for June and July indicated the proportion of CIIIs in the population to be between 30 and $80 \%$ and the proportion of CIIs to be between 5 and $45 \%$. What is clear is that by the following November both stages were virtually absent from the population. In the WSC, the pattern appeared superficially similar although the relative scarcity of winter samples makes interpretation difficult. In the EWS, an increased proportion of CIIs was seen in late April but not of CIIIs, which showed no obvious seasonal trends. Of the later stages in the northern region, CVs increased synchronously with males and females from August onwards and then declined in relative importance as the new generation was recruited. The percentage composition data (Fig. 5a) clearly shows trends of recruitment and the decrease over winter, particularly of Cills. Changes in mean abundance of the older stages (CIV to CVI) were seen from September onwards in the NR (Fig. 5b). The proportion of CIVs initially rose and then declined whilst that of CVs and females rose, peaked in November-December and then generally declined erratically into early winter. The number of CIVs increased again in February and declined into early winter. Overwintering numbers of older stages was low. Nonetheless despite low overall abundance during the early winter period, by August the relative proportion of the stages was changing and moulting was occurring well in advance of the spring bloom.

In the EWS, minima of stages CI to CIII occurred in January at the same time that the proportion of females was greatest (Fig. 5a). However, unlike the $N R$, the temporal resolution was insufficient to observe more than an increase between early February and late April. The percentage peak of females seen in February was accompanied by a decrease in the percentage composition of stages CIV and CV whereas increases in mean abundance in all 3 stages occurred between February and April.

Because of the significance of the winter period in understanding the life cycle a multivariate examination of percentage stage frequency data from the NR and EWS was carried out for the period April to October to compare overwintering population structure. Samples from the WSC were omitted from this analysis, as for the period in question they were few in number. Principal Components Analysis (PCA) based on the correlation data of the \% data showed that $67 \%$ of the total variation in the copepodite stages could be represented in 2 dimensions. Fig. 6 shows a bi-plot of the results, which represents the samples in the reduced space and also shows the direction and relative magnitude of the original variables in this space. Despite variability within each region there was a clear distinction in ordination space between them broadly separating out along the \% CII and \%CV vectors (Fig. 6). Subsequent examination of individual stage frequency distributions indicated that in many of the samples from the NR CIII was the dominant stage and that the majority of samples (21 of 31) were unimodal. In contrast, in the EWS, CIIIs were either absent or contributed a low proportion of the total stages. Bimodality (modal peaks CII and CV-CVI) was a feature of many of the samples (12 of 16). A pooled summary of these hauls is given in Fig. 7 .

\section{DISCUSSION}

\section{Regional abundance}

Rhincalanus gigas has an extensive and circumpolar distribution in the Southern Ocean (Baker 1954, Voronina 1970), which based on our analysis is centered around the APF and PFZ. This is consistent with the findings of Ommanney (1936), although Atkinson (1991), when plotting the mean abundance from 'Discovery' transects in the Scotia Sea, found it to be equally abundant in the SAF region. Reduced abundance in the Weddell Sea was also noted by Ommanney (1936) and Bathmann et al. (1993) and the species is essentially an inhabitant of the POOZ. Variations in abundance in the different parts of an organism's range are linked to its ability to reproduce successfully and for the progeny to survive and reproduce again, in which context generation time, lifetime fecundity and mortality will be important factors. Rates of emigration/immigration will also be critical and it has been suggested by Ommanney (1936) that $R$. gigas can be advected southwards into the Weddell Sea during winter when it is resident in the warm deep water. Bathmann et al. (1993) further suggest that here $R$. gigas only reproduces successfully in the region of the Maud Rise $\left(64^{\circ} 30^{\prime}\right.$ to $66^{\circ} \mathrm{S}, 0^{\circ}$ to $\left.2^{\circ} \mathrm{E}\right)$. A largely expatriate population which can only reproduce within a restricted area might imply a low abundance but other factors such as a restricted spawning period with females only being present in surface layers for a limited period compared to further north and the possibility of an extended life cycle (see below) are also important. The presence of nauplii in samples taken in the Western Weddell Sea during January (Schnack-Schiel 
a
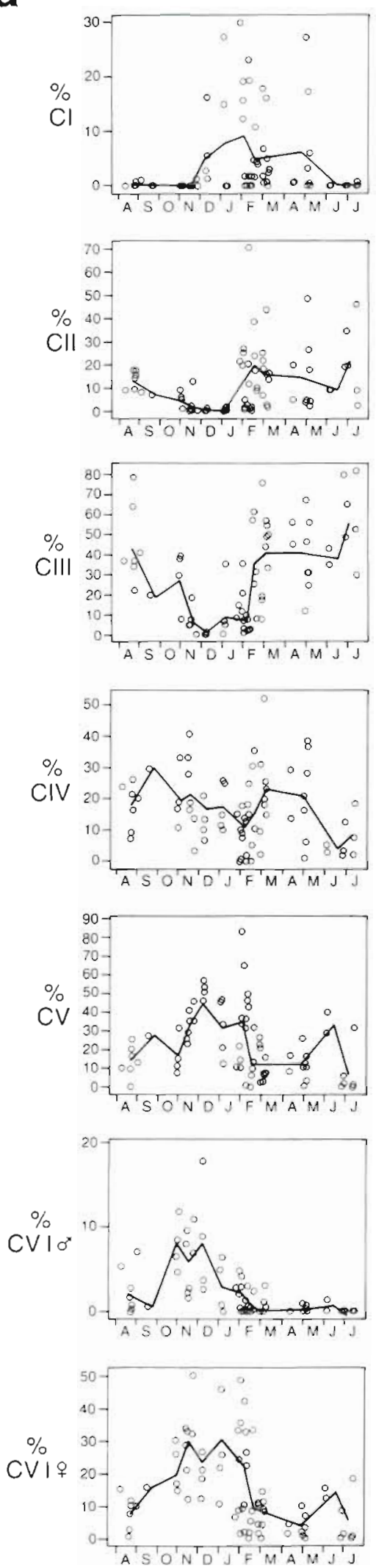

Month
Weddell-Scotia Confluence

Eastern Weddell Sea
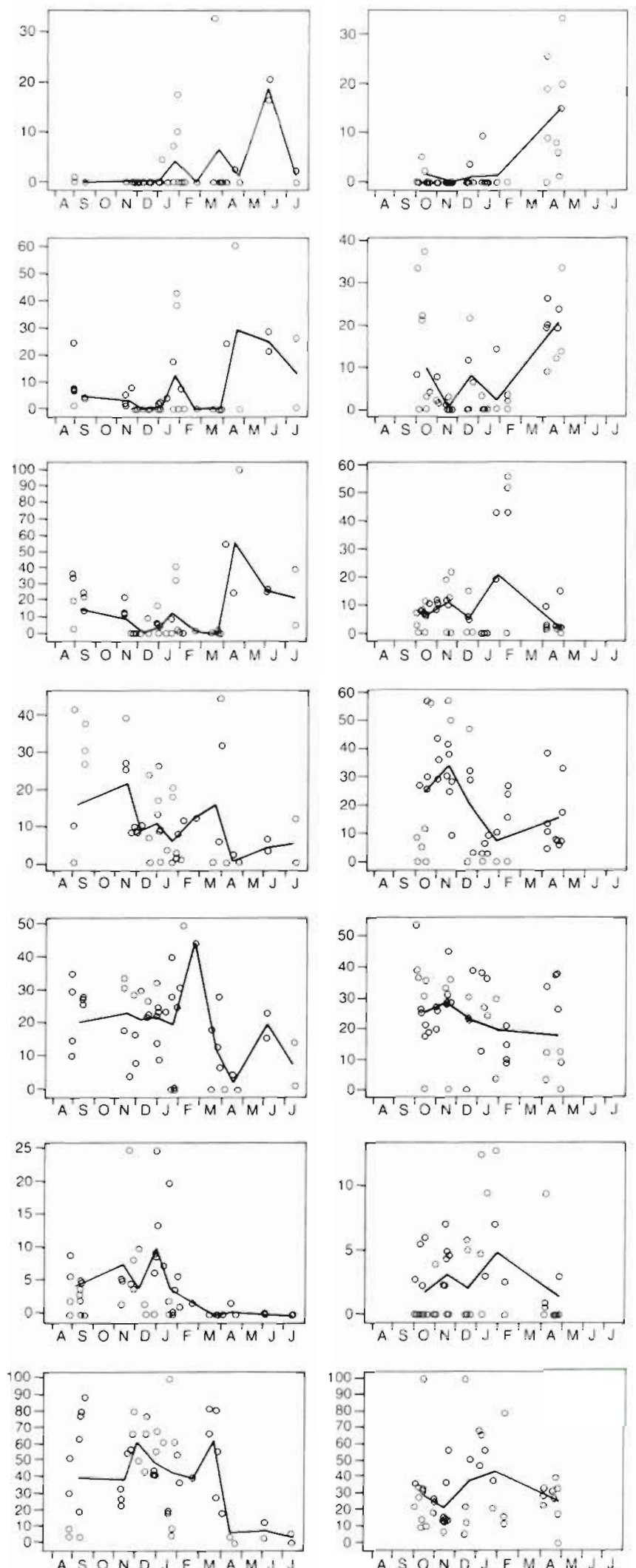

Month

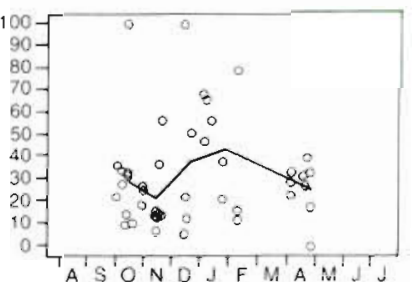

Month 

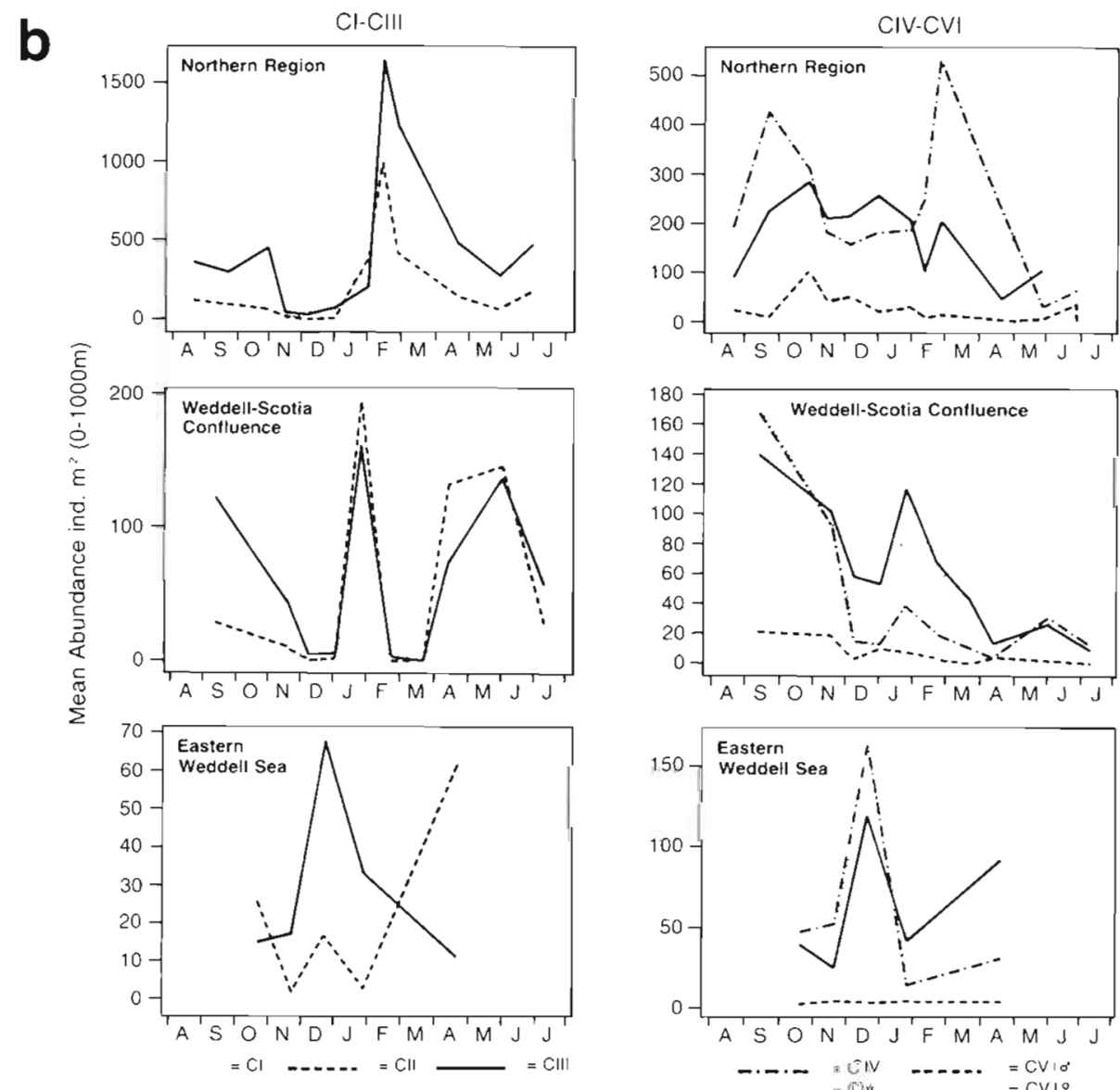

Fig. 5. Rhincalanus gigas. (a, facing page) Percentage composition of all copepodite stages (Cl to CVI) with respect to time of year. Lines link mean data values following grouping broadly on the basis of monthly occurrence. (b) Mean abundance values of all copepodite stages (CI to CVI) with respect to time of year. Lines link data averaged in the same way as in (a). Some data points have been omitted for clarity

unpubl. data), of ripe females in samples taken in the EWS (Hagen \& Schnack-Schiel 1996) and the presence of newly recruited CIs in April demonstrates that spawning does take place outside of the Maud Rise area. The residence time of water in the Weddell Gyre has been estimated as between 2 and 25 yr (Deacon 1979), clearly sufficient for the completion of life cycles (Hopkins \& Torres 1988), and so the population can be partially self sustaining. We know little about the fecundity of $R$. gigas in this region but experiments carried out by Ward \& Shreeve (unpubl. data) demonstrate that egg hatching at $0^{\circ} \mathrm{C}$ takes $\sim 9 \mathrm{~d}$ compared to $4.5 \mathrm{~d}$ at $5^{\circ} \mathrm{C}$. In light of this it seems probable that lower temperatures will also tend to extend development times of later stages. This and the fact that females are present in surface waters for a restricted period (cf. the NR) suggests a lower fecundity, although the generation time and the ability of females to overwinter and accompanying mortality rates will be crucial. The low abundance found in the WSC may reflect the influence of Weddell Sea water on the population although as is discussed below, aspects of its life cycle are somewhat similar to the NR.

\section{Timing of the life cycle}

The extent to which Rhincalanus gigas is herbivorous and, therefore, dependent on seasonal production for reproduction and growth has been actively discussed in the literature and the balance of opinion supports the view that it is predominantly herbivorous. Gut content analyses have indicated a low incidence of thecate protozoans and metazoans in its gut (Hopkins \& Torres 1989) and have also supported the view that this species is trophically inactive during winter (Hopkins et al. 1993) although Marin \& Schnack-Schiel (1993) found it eating diatoms in May. Feeding experiments reported by Schnack et al. (1985), Atkinson (1994) and Atkinson et al. (1996) concur that during the summer and autumn periods diatoms are the main food consumed. During spring in the Bellingshausen Sea an absence of predatory behaviour was noted in distinct contrast to co-occurring species such as Calanus propinquus and Metridia gerlachei (Atkinson 1995). Lipid analysis and fatty acid composition also support the idea of a predominantly herbivorous diet (Graeve et al. 1994, Kattner \& Hagen 1995, Ward et al. 


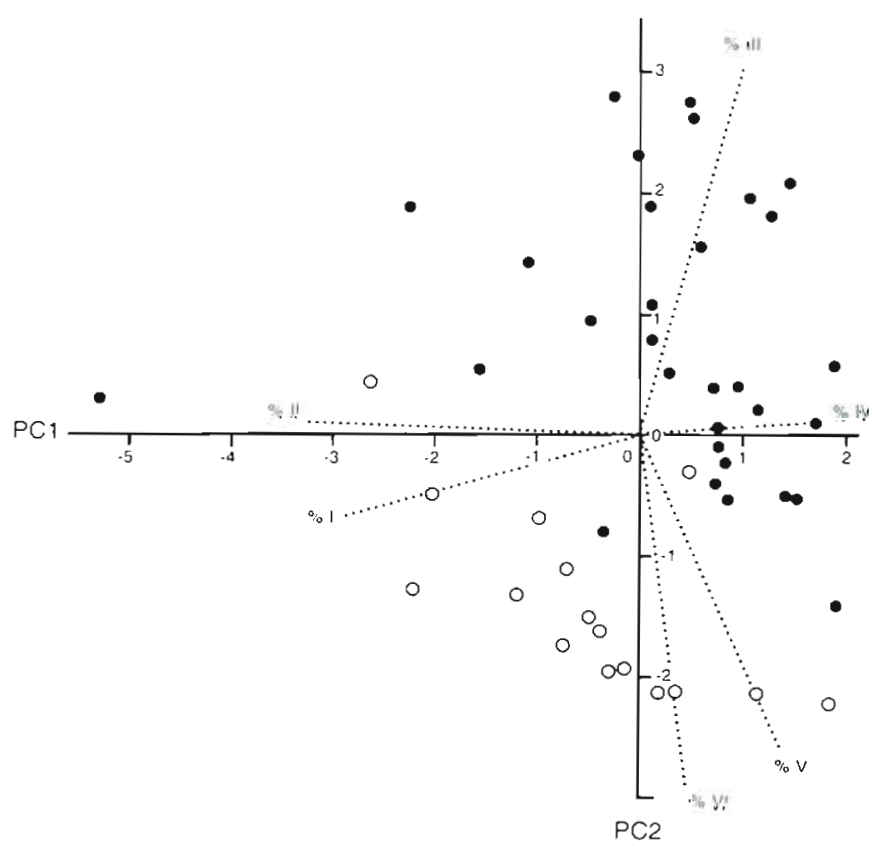

Fig. 6. Rhincalanus gigas. Principal Component ordinations of percentage stage composition for the NR and EWS winter samples (late April to October). Data used are described in the text. Percentage variance accounted for: $\mathrm{PC} 1=35 \%$, $\mathrm{PC} 2=32 \%, \mathrm{PC} 3=18 \%, \mathrm{PC} 4-6=15 \%$. (•) NR, (O) EWS

1996b) although Graeve et al. (1994) suggested that it was more omnivorous than Calanoides acutus. Crustacean remains are reported as having been found in the guts during winter (Arashkevich 1978 cited in Pasternak et al. 1994, Bathmann et al. 1993) and this needs confirmation. However in light of the species overwintering at depth in all regions and the delay of almost 3 mo in the arrival of the population in the surface waters in the EWS compared to the northern region, it seems reasonable to conclude that phytoplankton availability has a major impact on the timing of the life cycle. Voronina (1970) established such a lag for this species and also for C. acutus and C. propinquus which she related to the progressively later appearance of the phytoplankton maximum further south, first proposed by Hart (1942). It has been suggested that both gonad maturation and egg production in R. gigas are food limited (Ward \& Shreeve 1995, Ward et al. 1996a) and the significance of reported spawning/recruitment events outside the main production period needs to be assessed in light of this. There are recorded instances of nauplii and young copepodite stages occurring in May and June in the region of the Antarctic Peninsula (Marin \& SchnackSchiel 1993), also in samples from the WSC in June (this paper), at the pack ice edge south of Australia in late May (Ommanney 1936) in the region of the divergence of the Antarctic Coastal Current and the Antarc- tic Circumpolar Current. Bathmann et al. (1993) report nauplii south of South Georgia near the WSC during September/October and suggest that reproduction in the region of the Maud Rise takes place late in the season. These observations have been recorded either in places where blooms were occurring (Marin \& Schnack-Schiel 1993, Bathmann et al. 1993) or where physical conditions such as convergence/divergence areas may promote their occurrence. Their significance to overall recruitment and hence structure of the populations, at least in the NR, appears to be small (relatively few Cls overwinter, see Fig. 5a) although an assessment of the other areas is made difficult by the scarcity of winter samples. Nonetheless females are present year round in all regions and may be able to respond opportunistically to the presence of food outside of the main period of primary production.

\section{Development rates and longevity}

In our assessment of these characteristics there are distinct differences between the NR and the EWS. We therefore deal with these regions before turning to the WSC, which appears intermediate in some respects.

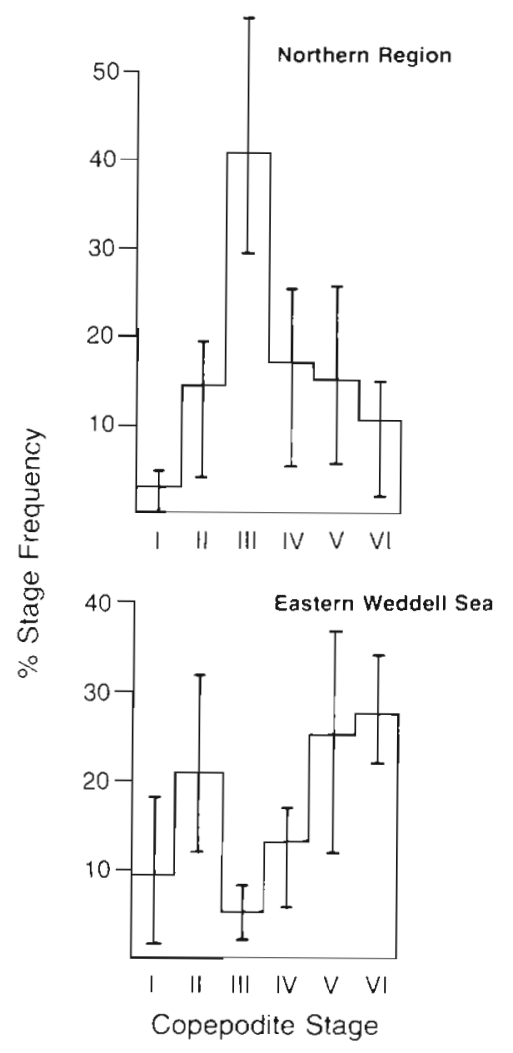

Fig. 7. Rhincalanus gigas. Mean stage frequency compositions in the NR and EWS regions for the winter period (late April to October). Bars represent interquartile ranges 


\section{Northern region}

The age structure of this species is variable among stations with more than 2 or 3 developmental stages being present at any time of year This has led to difficulties in interpretation which, coupled with protracted recruitment (Marin 1988a, b, Atkinson 1991) and reported low growth rates (Schnack et al. 1985), has led to the suggestion of a 2 yr life cycle (Marin $1988 \mathrm{a}$, b). Low weight-specific ingestion rates have been reported repeatedly (e.g. Schnack et al. 1985 Atkinson et al. 1992, 1996) and are also suggestive of low growth. However in the NR where the temporal resolution of sampling is finer and the number of samples larger, development through stages $\mathrm{CI}$ to CIV takes place within the space of approximately 2 mo (Fig. 5a, b). The virtual disappearance from the population of overwintered CI to CIIIs during November and December implies that the stock of CIVs recruited from February onwards is largely derived from the current year's generation. This rapid succession may in part be the result of averaging over different subregions where recruitment is taking place at different times, but moulting rate experiments carried out during January and February 1996 in the region of South Georgia and the Polar Front (Shreeve \& Ward unpubl. data) confirm that development can be rapid. Combining stage durations from these experiments gave a development rate of $37 \mathrm{~d}$ from appearance of $\mathrm{CI}$ to the appearance of CIV (74 d CI to CV). No instances of CVs moulting to females were recorded however during these 2 mo. It is unclear whether the June increase in CVs (Fig. 5) reflects recruitment or interannual variation in abundance. This stage is always present in the population and in terms of abundance appears to decline erratically from a peak in September. It may be that lower growth rates and the requirement to store lipid prior to overwintering largely restrict its appearance in the population until the following spring. All of the older stages (CIV to CVI) declined to their lowest levels in July and the main overwintering stage was CIII. Abundance of stages CIV to CVI increased dramatically from August to mid September associated with an accompanying decline in CII and CIII and these older stages dominated the population from November to January. Although not calculated because they were not enumerated consistently in the raw data, peaks of nauplii were observed from November to late January. The decline in abundance of the older stages in the middle of winter is puzzling. It is coincident with the period when the median population depth is greatest although as only a relatively small proportion of the population overwinters at depths $>1000 \mathrm{~m}$ it seems to be real. Additionally overall the population mortality is low particularly during winter (see below).
These data are problematic in terms of deciding the length of the life cycle. Clear differences can be seen between the overwintering stage structure of this species and Calanoides acutus for which Atkinson et al. (1997) suggest a predominantly 1 yr life cycle in both the Scotia Sea and EWS regions. This was characterised by adults appearing in the population during late winter, a period of recruitment restricted largely to spring followed by the virtual disappearance of the adult stock and their replacement by the overwintering stock comprising almost exclusively stages CIV and CV. For a 2 or multiyear life cycle representatives of at least 2 generations should be present post recruitment and bi- or polymodal distributions should be seen during the winter period, with the new generation significantly outnumbering the older ones.

The presence of females throughout the year does not preclude a 1 yr life cycle, but suggests that at least some are able to overwinter and possibly reproduce again. Similarly stages CIV and CV, although declining to low levels, particularly during winter, persist in the population all year. Whether this arises because there is a mixing of generations during the summer when some CIVs and CVs from the previous year fail to moult and mix with early maturing copepodites from the current generation or whether they form an overwintering cohort is not immediately obvious. For an organism such as Rhincalanus gigas which exhibits large adult body size, low weight-specific growth and where reproductive processes appear to be largely food limited it is puzzling that moulting rates, and we assume growth, appear to be rapid during the classically food limited period during late winter. Intuitively we would not have been surprised if, as Miller et al. (1984) have proposed for Eucalanus bungii in the subarctic Pacific and Marin (1988a, b) suggested for this species, the life cycle in all regions exceeded $1 \mathrm{yr}$. The major difficulty in interpreting our NR data in this way is the absence of significant numbers of overwintering late stages which suggests that here the majority of adults in the population are only 1 yr old.

\section{Eastern Weddell Sea}

Winter data from this region are sparse. The presence of nauplii in January in the western part of the Weddell Gyre and the appearance of stages CI and CII in late April suggest that recruitment again takes place when the population reaches the surface waters. Temporal resolution is low as is the overall abundance of the early stages, but Figs. $5 \& 7$ show that $\mathrm{CII}$ is one of the main overwintering stages, which is also suggested for some of the stations studied in Bathmann et al. (1993). The younger stages persist in the population 


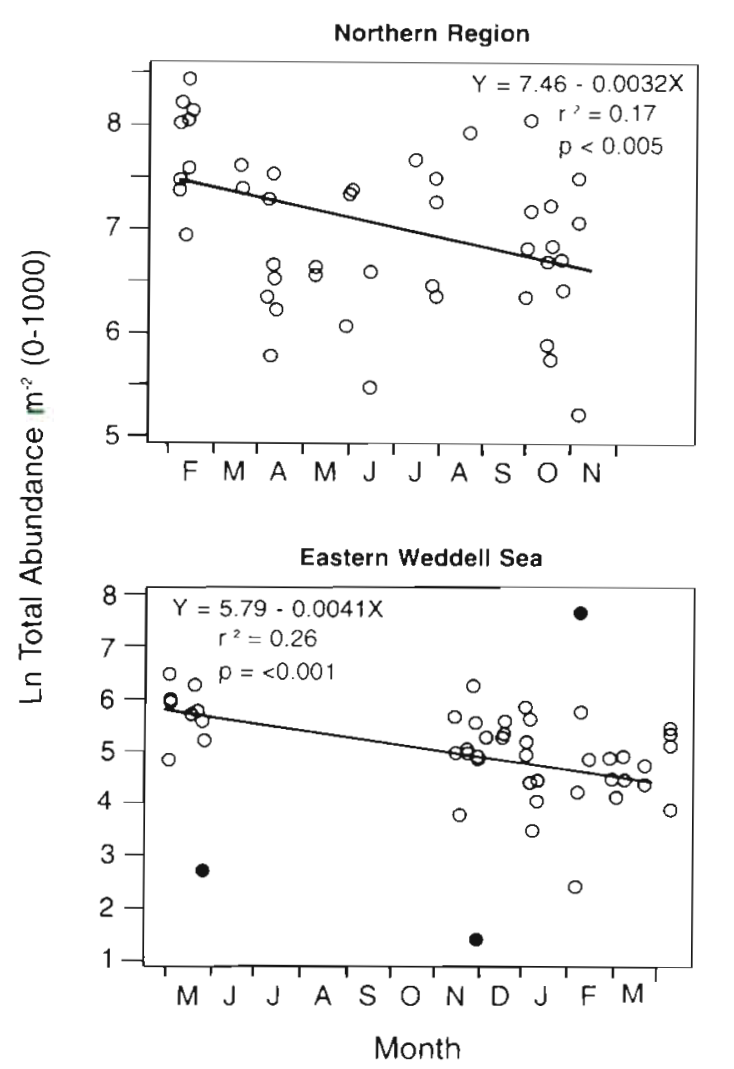

Fig. 8. Rhincalanus gigas. Total population mortality estimated in the NR and the EWS from total abundance data. Estimates commence from the time when recruitment is thought to be complete until prior to recruitment the following season (February to November in the NR, late April to February in the EWS). (-) Data points omitted from the regression on the basis of large residuals

until mid summer the following year, when an increase in stages CIV and CV is seen. Females dominate from November/December through until April. Thus in contrast to the NR, CIV and CV also form a significant proportion of the overwintering population. This distinction was also clearly implicated as a reason for the clear differences in the ordination between the NR and EWS samples (Fig. 6). It is therefore probable that females are not ready to spawn until their second summer and the generation time for the majority of the population in the EWS is 2 yr. Bathmann et al. (1993) suggest that females may re-enter diapause in the central part of the Weddell Sea and on the basis of the stage frequency composition the same is probably true in the present analysis.

The fact that the seasonal change in population abundance is relatively small compared to other biomass dominant species (Atkinson 1991) and our suggestion of a 2 yr life cycle in the EWS suggest that population mortality should be low. We have esti-
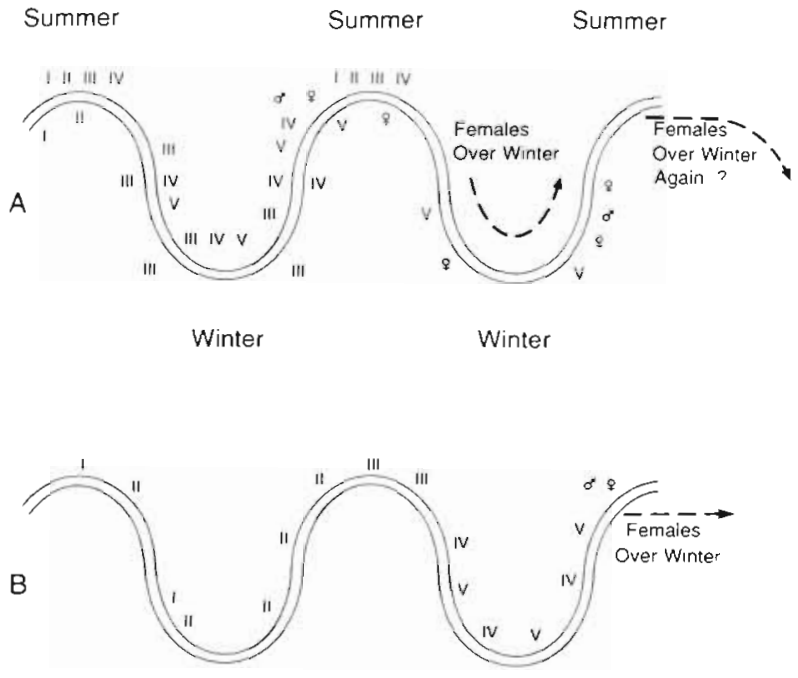

Fig. 9. Rhincalanus gigas. Schematic representations of 1 and 2 yr life cycles. Time is represented horizontally and depth vertically. (a) NR: timing of stages above curve is a suggested 1 yr life cycle. Below curve a proportion of the population persisting as late copepodite stages or late moulted females throughout a second summer. (b) EWS: suggested $2 \mathrm{yr}$ life cycle

mated mortality in the northern region from a point where population recruitment is essentially complete (February) until just prior to the next appearance of CIs (November). Although some recruitment is apparent in April (which would act to decrease the apparent mortality rate) numbers are comparatively low (Fig. 5b). On the same basis, we have estimated mortality from late April until February in the EWS. The mortality rate was similar in both regions $\left(<0.004 \mathrm{~d}^{-1}\right)$ and April to September data from the NR suggest that winter rates may be lower than this (Fig. 8). On the basis of a 1 yr life cycle 30 to $35 \%$ of the NR's February copepodid population would survive until November/December although this may include a proportion of second year overwintering females. In the EWS where a 2 yr life cycle is suggested, $25 \%$ of the April population would remain the following April and $-10 \%$ would survive to spawn the following December. Possible life cycles discussed above are presented schematically in Fig. 9.

\section{Weddell-Scotia Coniluence}

In this oceanographically complex transition region a somewhat variable population composition can be seen. Overall abundance is low and similar to that found in the EWS although whether this reflects the influence of Weddell Sea waters or other factors is not clear. Newly recruited stages CI to CIII appear 
around the beginning of January and until June/July comprise a variable proportion of the population although they have virtually disappeared by the following December. Spawning must therefore have commenced at least 1 mo prior to their appearance (allowing for naupliar development) coincident with the period when females consistently comprised around $50 \%$ of the total population. Stages CIV and $\mathrm{CV}$ comprise variable proportions of the population between September and November and then decline somewhat erratically to reach early overwintering minima similar to that observed in the NR. Females and males dominate the population from September onwards until the new generation appears, implying that the majority of stages CIV and CV moult quickly into adults and are not generally overwintering stages, although the data for September are equivo$\mathrm{cal}$ in this respect. Low early overwintering numbers of later stages are also suggestive of a 1 yr life cycle with the probability that a variable number of females overwinter and survive into their second summer. The extent to which the variable influence of the neighbouring water masses affects population processes is unclear, although year to year variations are to be expected, dependent on which exerts the dominant influence.

In all regions moulting is mostly initiated well before the spring bloom. It is unlikely that structural growth in Rhincalanus gigas is achieved entirely by lipid mobilization at this time as the difference in mass between CIII, CIV and CVs and adults is considerable (Conover \& Huntley 1991, Schnack-Schiel \& Hagen 1994, authors' unpubl. data). Rapid spring moulting (pulse moulting) of CIV and CV Calanoides acutus has been observed by Huntley et al. (1994) in the Bransfield Strait region during October when $80 \%$ of CVs moulted to adults within $15 \mathrm{~d}$, a rate much faster than experienced later in the season. A similar pattern is seen for $C$. acutus in all 3 regions (Atkinson et al. 1997) with males appearing in the NR as early as August and in the EWS in October and females slightly later. However CIs were not apparent until late November to January in the NR and February in the EWS when more food is likely to have been available. Spawning in this species, particularly in the NR, appears to commence prior to any significant increase in food levels as blooms in this area in November are rare (Tréguer \& Jacques 1992, although see El-Sayed \& Weber 1982). R. gigas appears to follow a similar pattern, at least in terms of rapid moulting to the adult stage, but the new generation appears later than $C$. acutus in all areas. It is likely that egg production is food limited to a greater extent than in C. acutus and an external food supply is required.

\section{Conclusions}

The 'flexibility' attributed to Rhincalanus gigas appears to be linked to its ability to withstand food shortages and in particular for early copepodite stages to overwinter Unlike Calanoides acutus, which appears to be able to complete its life cycle in $1 \mathrm{yr}$ even in the EWS, $R$. gigas appears to be able to accomplish this only in the NR and possibly in the WSC. The relative effects of temperature and food on development rates are difficult to discern in this environment. Atkinson et al. (1997) concluded that on balance slightly higher phytoplankton biomass in the EWS may offset any tendency of a lower temperature to extend generation time in C. acutus. This appears insufficient to enable $R$. gigas to complete its life cycle in 1 yr here and it may be that its larger size and lower weight-specific growth rates, particularly of the older copepodids, mean that the relative shortness of the production season in the EWS is of critical importance. However, the ability of young copepodite stages to overwinter coupled with a low population mortality strongly suggests that $R$. gigas can survive periods of food limitation and overwinter for a second time in the NR if required and in the EWS as a matter of necessity.

Acknowledgements. We thank those people who over the years have expended a great deal of time and effort collecting zooplankton samples often under arduous conditions. We are grateful to Dr U. Bathmann for making his data available to us and to Dr J. Priddle and the referees for commenting on the manuscript. This is contribution number 1250 of the AlfredWegener-Institut für Polar- und Meeresforschung.

\section{LITERATURE CITED}

Arashkevich EG (1978) Some characteristics of feeding of copepods. Tr Inst Okeanol Akad Nauk SSSR 112:118-121

Atkinson A (1989) Distribution of six major copepod species around South Georgia in early summer. Polar Biol 9: $353-363$

Atkinson A (1991) Life cycles of Calanoides acutus, Calanus simillimus and Rhincalanus gigas (Copepoda: Calanoida) within the Scotia Sea. Mar Biol 109:79-91

Atkinson A (1994) Diets and feeding selectivity among the epipelagic copepod community near South Georgia in summer. Polar Biol 14:551-560

Atkinson A (1995) Omnivory and feeding selectivity in five copepod species during spring in the Bellingshausen Sea, Antarctica. ICES J Mar Sci 52:385-396

Atkinson A, Schnack-Schiel SB, Ward P, Marin V (1997) Regional differences in the life cycle of Calanoides acutus (Copepoda: Calanoida) within the Atlantic sector of the Southern Ocean. Mar Ecol Prog Ser 150:99-111

Atkinson A, Shreeve RS, Pakhomov EA, Priddle J, Blight SP, Ward P (1996) Zooplankton response to a phytoplankton bloom near South Georgia, Antarctica. Mar Ecol Prog Ser $144: 195-210$ 
Atkinson A, Ward P, Willams R, Poulet SA (1992) Feeding rates and diel vertical migration of copepods near South Georgia: comparison of shelf and oceanic sites. Mar Biol $114: 49-56$

Baker A de C (1954) The circumpolar continuity of Antarctic plankton species. 'Discovery' Rep 27:201-218

Bathmann U, Makarov RR, Spirodonov VA, Rohardt G (1993) Winter distribution and overwintering strategies of the Antarctic copepod species Calanoides acutus, Rhincalanus gigas and Calanus propinquus (Crustacea Calanoida) in the Weddell Sea. Polar Biol 13:333-346

Conover RJ, Huntley M (1991) Copepods in ice-covered seas - distribution, adaptation to seasonally limited food, metabolism, growth patterns and life cycle strategies in polar seas. J Mar Syst 2:1-41

Deacon GER (1979) The Weddell Gyre. Deep Sea Res 26 981. -995

El-Sayed SZ, Weber LH (1982) Spatial and temporal variation in phytoplankton biomass and primary productivity in the southwest Atlantic and the Scotia Sea. Polar Biol 1:83-90

Gloersen P, Campbell WJ, Cavalieri DJ, Comiso JC, Parkinson $\mathrm{CL}$, Zwally HJ (1992) Arctic and Antarctic sea ice, 1978-1987: satellite passive-microwave observations and analysis. National Aeronautics and Space Administration, Washington, DC

Graeve M, Hagen W, Kattner G (1994) Herbivorous or omnivorous? On the significance of lipid compositions as trophic markers in Antarctic copepods. Deep Sea Res 41:915-924

Hagen W, Kattner G, Graeve M (1993) Calanoides acutus and Calanus propinquus Antarctic copepods with different lipid storage modes via wax esters or triacyglycerols. Mar Ecol Prog Ser 97:135-142

Hagen W, Schnack-Schiel SB (1996) Seasonal lipid dynamics in dominant Antarctic copepods: energy for overwintering or reproduction? Deep Sea Res 43:139-158

Hart TJ (1942) Phytoplankton periodicity in Antarctic surface waters. 'Discovery' Rep 8:1-268

Hopkins TL, Ainley DG, Torres JJ, Lancraft TM (1993) Trophic structure in open waters of the marginal ice zone in the Scotia-Weddell confluence region during spring (1983). Polar Biol 13:389-397

Hopkins TL, Torres JJ (1988) The zooplankton community in the vicinity of the ice edge, Western Weddell Sea, March 1986. Polar Biol 9:79-87

Hopkins TL, Torres JJ (1989) Midwater food web in the vicinity of a marginal ice zone in the western Weddell Sea. Deep Sea Res 36:543-560

Huntley ME, Zhou M, Lopez MDG (1994) Calanoides acutus in Gerlache Strait, Antarctica. II Solving an inverse problem in population dynamics. Deep Sea Res II 41:209-227

Kattner G. Hagen W (1995) Polar herbivorous copepods- different pathways in lipid biosynthesis. ICES J Mar Sci 52: 329-335

Laubscher RK, Perissinotto R, McQuaid CD (1993) Phytoplankton production and biomass at frontal zones in the Atlantic sector of the Southern Ocean. Polar Biol 13: $471-481$

Mackintosh NA (1937) The seasonal circulation of the Antarctic macroplankton. 'Discovery' Rep 16:365-412

Marin V (1986) Distribution and life cycle of three antarctic copepods (Calanoides acutus, Calanus propinquus and Rhincalanus gigas). PhD thesis, University of California, San Diego

Marin V (1988a) Independent life cycles: an alternative to the asynchronism hypothesis for antarctic calanoid copepods. In: Boxshall GA, Schminke HK (eds) Biology of copepods. Hydrobiologia 167/168:161-168
Marin V (1988b) Qualitative models of the life cycles of Calanoides acutus, Calanus propinquus and Rhincalanus gigas. Polar Biol 8:439-446

Marin VH, Schnack-Schiel SB (1993) The occurrence of Rhincalanus gigas, Calanoides acutus and Calanus propinquus (Copepoda: Calanoida) in late May in the area of the Antarctic Peninsula. Polar Biol 13:35-40

Miller CB, Frost BW, Batchelder HP, Clemons MJ, Conway RE (1984) Life histories of large, grazing copepods in a subarctic ocean gyre: Neocalanus plumchrus, Neocalanus cristatus and Eucalanus bungii in the Northeast Pacific Prog Oceanogr 13:201-243

Ommanney FD (1936) Rhincalanus gigas (Brady) a copepod of the southern macroplankton. 'Discovery' Rep 13 $231-334$

Orsi AH, Nowlin WD, Whitworth T III (1993) On the circulation and stratification of the Weddell Gyre. Deep Sea Res 40:169-203

Pasternak AF, Kosobokova KN, Drits AV (1.994) Feeding metabolism and body composition of the dominant Antarctic copepods with comments on their life cycles. Russ J Aquat Biol 3:49-62

Sakshaug E (1989) The physiological ecology of polar phytoplankton. In: Rey L, Alexander V (eds) Marine living systems of the far north. Brill, Leiden, p 61-89

Savidge G, Priddle J, Gilpin LC, Bathmann U, Owens NJP Pollard RT, Turner DR, Veth C, Boyd PW (1996) An assessment of the role of the marginal ice zone in the carbon cycle of the Southern Ocean. Antarct Sci 8:349-358

Schnack SB, Smetacek V, von Bodungen B, Stegmann P (1985) Utilization of phytoplankton by copepods in Antarctic waters during spring. In: Gray JS, Christiansen ME (eds) Marine biology of polar regions and the effects of stress on marine organisms. Wiley, Chichester, p 65-81

Schnack-Schiel SB, Hagen W (1994) Life cycle strategies and seasonal variations in distribution and population structure of four dominant calanoid copepod species in the eastern WeddeIl Sea, Antarctica. J Plankton Res 16 $1543-1566$

Smetacek V, Scharek R, Gordon LI, Eicken H, Fahrbach E Rohardt G, Moore S (1992) Early spring phytoplankton blooms in ice-platelet layers in the southern Weddell Sea, Antarctica. Deep Sea Res 39:153-168

Tréguer P, Jacques G (1992) Dynamics of nutrients and phytoplankton, and fluxes of carbon, nitrogen and silicon in the Antarctic Ocean. Polar Biol 12:149-162

Vladimirskaya YeV (1978) Age composition of winter populations of abundant copepod species in the southern part of the Scotia Sea. Oceanology 18:202-204

Voronina NM (1970) Seasonal cycles of some common Antarctic copepod species. In: Holdgate MW (ed) Antarctic ecology. Academic Press, New York, p 162-172

Voronina NM, Vladimirskaya YeV, Zmiysvskaya MI (1978) Seasonal variations in the age composition and vertical distribution of common zooplankton species in the Southern Ocean. Oceanology 18:335-338

Ward P, Atkinson A, Murray AWA, Wood AG, Williams R, Poulet SA (1995) The summer zooplankton community at South Georgia: biomass, vertical migration and grazing. Polar Biol 15:195-208

Ward P. Shreeve RS (1995) Egg production in three species of Antarctic calanoid copepods during an austral summer. Deep Sea Res 42:721-735

Ward P. Shreeve RS, Cripps GC (1996a) Rhincalanus gigas and Calanus simillimus: lipid storage patterns of two species of copepod in the seasonally ice-free zone of the Southern Ocean. J Plankton Res 18:1439-1454 
Ward P, Shreeve RS, Cripps GC. Trathan PN (1996b) Mesoscale distribution and population dynamics of Rhincalanus gigas and Calanus simillimus in the Antarctic Polar Open Ocean and Polar Frontal Zone during summer. Mar Ecol Prog Ser 140:21-32

Wefer $G$, Fischer G (1991) Annual primary production and

Editorial responsibility: Otto Kinne,

OldendorflLuhe, Germany export flux in the Southern Ocean from sediment trap data. Mar Chem 35:597-614

Whitworth T Ill, Nowlin WD Jr, Orsi AH, Locarnini RA, Smith SG (1994) Weddell Sea shelf water in the Bransfield Strait and Weddell Scotia Confluence. Deep Sea Res 41: $629-641$

Submitted: May 13, 1997; Accepted: August 13, 1997 Proofs received from author(s): October 7, 1997 